\author{
MARIAN MACHINEK \\ Uniwersytet Warmińsko-Mazurski w Olsztynie \\ Wydział Teologii
}

\title{
Wspólny dom. „Ekologiczna" encyklika papieża Franciszka
}

The common house. The "Ecological" Encyclical of Pope Francis

Wydana w 2015 roku encyklika papieża Franciszka zatytułowana Laudato si'. $W$ trosce o wspólny dom jest niewątpliwie dokumentem wyjątkowym. Problematyka ekologiczna była oczywiście podejmowana przez poprzedników Franciszka na Stolicy Piotrowej. Działo się to zazwyczaj w kontekście nauczania dotyczącego problemów społecznych i życia gospodarczego ${ }^{1}$. Ostrzeżenia przed bezmyślnym niszczeniem środowiska naturalnego pojawiały się często $\mathrm{w}$ wypowiedziach Jana Pawła II, który witał z nadzieją wzrastające zainteresowanie jakością życia oraz właśnie ekologią, dzięki któremu można zwiększyć wysiłki w celu globalnego polepszenia warunków życia ${ }^{2}$. O odpowiedzialności za stan środowiska naturalnego wobec ubogich, przyszłych pokoleń oraz całej ludzkości przypominał także Benedykt $\mathrm{XVI}^{3}$. Sam papież Franciszek wielokrotnie wskazywał wcześniej na znaczenie problematyki ekologicznej, stwierdzając, że zaangażowanie w kwestie ochrony środowiska jest kontynuacją Bożego dzieła stworzenia ${ }^{4}$. Franciszek sta-

${ }^{1}$ Zob. L. Roos, Die Sozialenzykliken der Päpste, w: Handbuch der Katholischen Soziallehre, red. A. Rauscher, Berlin 2008, s. 125-142.

2 EV 27. Wśród szeregu wypowiedzi Jana Pawła II na tematy ekologiczne warto wymienić chociażby przesłanie na Światowy Dzień Pokoju w 1990 r., które w całości poświęcone było tematyce ekologicznej. Zob. Jan Paweł II, Pokój z Bogiem Stwórca, pokój z całym stworzeniem, http: //papiez.wiara.pl/doc/378717.Pokoj-z-Bogiem-Stworca-pokoj-z-calym-stworzeniem-1990 [dostęp: 25.05.2016].

${ }^{3} \mathrm{CiV} 48$.

${ }^{4}$ Franciszek, Medytacja podczas Mszy św. 9 lutego 2015, http://w2.vatican.va/content/france sco/it/cotidie/2015/documents/papa-francesco-cotidie_20150209_al-lavoro-con-dio.html [dostęp: 20.05.2016]. 
wia Laudato si' w rzędzie wypowiedzi swoich poprzedników, począwszy od Jana XXIII ${ }^{5}$. Mimo tego nie sposób nie dostrzec wyjątkowości tego dokumentu. Wraz z Laudato si' po raz pierwszy w historii Kościoła pojawia się oficjalny dokument Magisterium poświęcony $\mathrm{w}$ całości problematyce ochrony środowiska.

Celem niniejszego artykułu nie jest wyczerpujące omówienie całości papieskiej encykliki, ale raczej zbadanie jej głównych wątków i linii argumentacyjnych na tle nauczania poprzedników papieża Franciszka na Stolicy Piotrowej oraz w kontekście współczesnej refleksji teologii moralnej.

\section{PIĘKNO STWORZENIA}

Wbrew obawom, że papież Franciszek zaangażuje się po którejś ze stron toczących się sporów dotyczących konkretnych rozwiązań poszczególnych problemów ekologicznych, nie formułuje on w swojej encyklice żadnych gotowych rozwiązań. Jeżeli przywołuje fakty i dane dotyczące degradacji środowiska, to czyni to w celu zarysowania tła swojej wypowiedzi. Unika przy tym poglądów skrajnych, opierając się raczej na powszechnie przyjętych wynikach badań i zaznaczając, że są one często fragmentaryczne i nieostateczne. „W wielu kwestiach - jak zaznacza - Kościół nie ma podstaw, by proponować definitywne rozwiązania i rozumie, że powinien słuchać i promować uczciwą debatę wśród naukow-

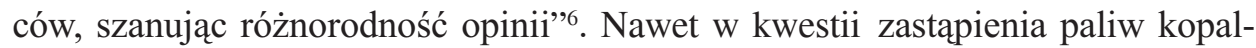
nych innymi źródłami energii, która w ostatnich latach bywa szczególnie kontrowersyjnie dyskutowana, Franciszek wypowiada się z rozwagą, opowiadając się za stopniowym eliminowaniem szkodliwych emisji, szczególnie dwutlenku węgla, z uwzględnieniem rozwiązań przejściowych ${ }^{7}$.

Głównym celem refleksji papieża Franciszka nie jest jednak analiza sytuacji. Jest nim raczej ukazanie głębokich korzeni kryzysu ekologicznego oraz odsłonięcie postaw, które sprawiaja, że kryzys ten wciąż się pogłębia. Nie ulega wątpliwości, że człowiek został w szczególny sposób wyróżniony przez Stwórcę zdolnościami i godnością, których nie posiada żadne inne stworzenie. Jednak, jak podkreśla Franciszek, panowanie człowieka nad światem, o którym mówią już pierwsze strony Biblii, nie może oznaczać bezmyślnej eksploatacji. Papież przytacza zdanie zawarte w Katechizmie Kościoła katolickiego, że „każde stworzenie posiada swoją własną dobroć i doskonałość"». Jak jednak pogodzić szacunek dla stworzenia ze słusznymi aspiracjami człowieka do korzystania z zasobów naturalnych? Franciszek twierdzi, że dopiero wtedy, gdy nie zapomina się o Stwórcy,

\footnotetext{
${ }^{5}$ LS 3-6.

${ }^{6}$ LS 61.

${ }^{7}$ LS 26 i 165.

${ }^{8}$ KKK 339.
} 
człowiek nie ulega pokusie bezmyślnego tratowania stworzonej przez Niego rzeczywistości i zajmowania miejsca należnego jedynie Bogu. Dopiero wtedy też potrafi on dostrzec, że (i tu papież cytuje św. Tomasza z Akwinu), ,przyroda jest niczym innym, jak pewnym rodzajem prawdziwej sztuki, a mianowicie Boskiej sztuki wpisanej w rzeczy"'.

Nieprzypadkowo Franciszek przywiązuje taką wagę do właściwego spojrzenia na ożywioną i nieożywioną naturę. Zanim świat stanie się obiektem ludzkich działań, ingerencji i eksploatacji, jest on po prostu znakiem dobroci i geniuszu Stwórcy. Ta niewyrażalna w wielkościach finansowych wartość świata musi być najpierw dostrzeżona, doceniona i wysmakowana na drodze kontemplacji, by człowiek mógł się później w adekwatny sposób odnieść do niej jako do surow$\mathrm{ca}^{10}$. Dla kogoś, kto umie tak patrzeć na świat, wszystko, co istnieje: gleba, woda, góry są językiem miłości Boga, „wyrazem czułości Boga" ${ }^{11}$. Takie nastawienie pozwala dostrzec, że pochodząc od tego samego Ojca, wszystkie byty są zjednoczone niewidzialnymi więzami i tworzą rodzaj uniwersalnej rodziny, pobudzającej do świętego, serdecznego i pokornego szacunku. Papież dotyka tu zagadnienia, które jest żywo dyskutowane we współczesnej refleksji w ramach różnych dziedzin wiedzy. Nie ulega wątpliwości, że teologiczne spojrzenie należy odróżnić od spojrzenia filozofii, a jeszcze bardziej od spojrzenia nauk przyrodniczych. Chociaż żadna $\mathrm{z}$ tych dziedzin nie jest $\mathrm{w}$ stanie dostępnymi jej narzędziami ująć i wyrazić wyczerpująco całej rzeczywistości, to jednak perspektywa każdej z nich jest istotna. Podczas gdy nauki przyrodnicze koncentrują się na wyjaśn i e n i u związków przyczynowo-skutkowych w ożywionej i nieożywionej przyrodzie, celem filozofii jest całościowe zrozumienie świata. By tego dokonać, nie wystarczy już metoda empiryczna charakterystyczna dla nauk przyrodniczych. Wreszcie z teologii i wiary chrześcijańskiej wyrasta jeszcze inna perspektywa, prowadząca do zadziwienia i dziękczynienia ${ }^{12}$, którą tak mocno podkreśla papież w swojej encyklice. Człowiek musi zmienić perspektywę z obserwatora i eksploratora zewnętrznej wobec niego rzeczywistości na uczestnika dziejących się w przyrodzie procesów, a patrząc oczami wiary - także na adresata daru, jakim jest stworzenie, i na mandatariusza Stwórcy ${ }^{13}$.

Ta postawa zachwytu nad pięknem stworzenia nie jest elementem dodatkowym do konkretnych działań proekologicznych, ale jest do tego stopnia postawą

9 LS 80.

10 Por. J. Römelt, Christliche Ethik in moderner Gesellschaft, 2 Lebensbereiche, Freiburg-Basel-Wien 2009, s. 322-324.

11 LS 84. Pojęcie czułości należy do ulubionych pojęć używanych przez papieża Franciszka. W kontekście Nadzwyczajnego Jubileuszu Miłosierdzia w 2016 r. nabiera ono szczególnego znaczenia zarówno dla wyrażenia miłości Boga do grzeszników, jak i powinności moralnej każdego wierzącego wobec bliźniego.

12 Por. M. Kehl, Schöpfung. Warum es uns gibt, Freiburg i. Breisgau 2005, s. 16-20.

13 F. Gruber, Im Haus des Lebens. Eine Theologie der Schöpfung, Regensburg 2001, s. 155-174. 
niezbędna, że właśnie jej brak staje się jednym z głównych źródeł kryzysu ekologicznego. Jeśli nie zostanie ona doceniona, np. w procesie wychowania młodego pokolenia, będzie to miało niewątpliwie konkretne negatywne skutki w przyszłości ${ }^{14}$, uniemożliwiając wręcz adekwatne i skuteczne działania proekologiczne. Potrzeba zatem czegoś więcej niż tylko kalkulacji. Potrzeba nowego spojrzenia na świat: jest on czymś więcej niż problemem do rozwiązania, jest on radosną tajemnica, którą podziwiamy w zachwycie, oddając chwałę Bogu ${ }^{15}$.

\section{ZRÓWNOWAŻONY ROZWÓj}

Jednym z istotnych pojęć współczesnej refleksji ekologicznej, a także encykliki papieża Franciszka, jest pojęcie zrównoważonego rozwoju (ang. Sustainability, niem. Nachhaltigkeit ${ }^{16}$ ). Punktem wyjścia jest tu nierozerwalne powiązanie człowieka z otaczającym go nieożywionym i ożywionym światem. Nie ulega wątpliwości, że można mówić o wzajemnym związku życia ludzkiego nie tylko ze środowiskiem naturalnym, ale także z wytworami ludzkiej kultury. Mamy tu wręcz do czynienia ze swego rodzaju „siecią” zależności, z której człowiek nie może się wyplątać ${ }^{17}$. Związek ten, w perspektywie teologicznej, wynika z prawdy o stworzeniu, które jako harmonijna całość wyszło z rąk Stwórcy. By wyrazić ten żywotny związek, Franciszek sięga po pojęcie domu, które stoi u podstaw myślenia ekologicznego (łac. oikos - dom). Jak powiada papież, „,wszystkie byty wszechświata, będąc stworzonymi przez tego samego Ojca, są zjednoczone niewidzialnymi więzami i tworzą rodzaj uniwersalnej rodziny, wspaniałej komunii pobudzającej do świętego, serdecznego i pokornego szacunku"18.

Przy założeniu, że ludzkość zachowuje szacunek i umiar, może ona czerpać ze środowiska naturalnego to, czego potrzebuje. Klasyczna katolicka nauka o powszechnym przeznaczeniu dóbr ${ }^{19}$ tego świata, która nie neguje prawa do wła-

${ }^{14}$ J. Mariański, Odpowiedzialność człowieka za środowisko naturalne i ekologię ludzka $w$ świetle społecznego nauczania Kościoła, w: Fructus Spiritus est caritas. Księga Jubileuszowa ofiarowana Księdzu Profesorowi Franciszkowi Draczkowskiemu, red. M. Wysocki, Lublin 2011, s. 814.

15 LS 12.

${ }_{16}$ Zob. M. Vogt, Das Konzept der Nachhaltigkeit, w: Handbuch der Katholischen Soziallehre, dz. cyt., s. 411-419.

17 W obszarze j. niemieckiego używa się pojęcia Retinität, które pochodzi od łacińskiego słowa rete - 'sieć'. Inne określenie to Vernetzung (niem. Netz - 'sieć'). Zob. W Korff, Lexikon der Bioethik, t. 1, Gütersloh 2000, s. 15. Zob. także E. Schockenhoff, Anthropozentrische und ökozentrische Ethik, w: Handbuch der Katholischen Soziallehre, dz. cyt., s. 410.

18 LS 89.

19 Przypominał tę prawdę już Leon XIII, a po nim Pius XII, Jan XXIII, a szczególnie Jan Paweł II. Warto w tym miejscu przywołać także soborową Konstytucję o Kościele w świecie współczesnym Gaudium et spes, w której stwierdza się, że „,własność prywatna posiada z natury swojej 
sności prywatnej, ale je poprzedza, a gdy jest to niezbędne - także ogranicza, zostaje w tym kontekście przypomniana także przez papieża Franciszka. Zgodnie $\mathrm{z}$ tą nauką środowisko jest dobrem publicznym, mieniem całej ludzkości i stąd na wszystkich ciąży odpowiedzialność za jego stan. Poczucie tej odpowiedzialności z niezwykłą siłą ujawniło się na przełomie XX i XXI wieku. Skoro ludzkość zdaje sobie z niej sprawę, to gdzie leży przyczyna dalszego dewastowania środowiska? Jednym z czynników jest, jak stwierdza Franciszek, niewłaściwe rozumienie postępu. Również ta myśl nie jest nowa w nauczaniu Kościoła ${ }^{20}$. Papież nie zamierza tu potępiać ludzkiej kreatywności, która dąży do doskonalenia narzędzi, jakimi posługuje się człowiek. Nauka i technologia są bez wątpienia wspaniałymi owocami twórczego ludzkiego rozumu, w który Stwórca wyposażył swoje stworzenie. Lecz te wspaniałe możliwości mogą uruchomić siły, które staną się źródłem jego samozniszczenia. Jak podkreśla Franciszek, istota ludzka nie jest w pełni autonomiczna, a jej wolność może ulec wypaczeniu, „gdy powierza się ją ślepym siłom podświadomości, doraźnym potrzebom, egoizmowi i brutalnej przemocy”21. To właśnie ten brak gotowości do samoograniczenia, a nie technika jako taka, jest powodem degradacji środowiska.

Innym istotnym czynnikiem jest konsumpcjonizm. Wyraża się on w postawie, którą Franciszek określa mianem ,użyj i wyrzuć”. Stoi ona u źródeł nieuporządkowanej konsumpcji przekraczającej znacznie faktyczne potrzeby i generującej ogromne ilości odpadów ${ }^{22}$. Nieokiełznany konsumpcjonizm prowadzi do „rozrzutnego i konsumpcyjnego nadrozwoju"23. W tym kontekście nie sposób nie dostrzec fenomenu, jakim jest globalizacja paradygmatu technokratycznego. Technokratyczny sposób myślenia polega na tym, że człowiek traktuje otaczający go świat wyłącznie jako materiał do przetworzenia, jakby była to bezkształtna masa, jedynie surowiec, który człowiek może wykorzystywać i urabiać bez żadnych ograniczeń. Ta technokratyczna egzaltacja sprawia, że człowiek nie przyznaje już innym istotom właściwej im wartości i nie postrzega siebie jako stworzenia, które ma twórczo pomagać w wyłanianiu się potencjalności, jakie Stwórca zawarł w rzeczach. Zamiast tego istota ludzka postępuje tak, jakby sama była stwórca. Innym czynnikiem jest ślepa wiara w nieograniczony rozwój, która spycha na dalszy plan odpowiedzialność za skutki podejmowanych przez człowieka

charakter społeczny, oparty na prawie powszechnego przeznaczenia dóbr" (KDK 71). Zob. także KNSK 171-184.

${ }^{20}$ Przed mitem postępu, od którego oczekuje się rozwiązania wszystkich problemów trapiących ludzkość, przestrzegał z naciskiem Benedykt XVI. Por. CiV 68-71. Zob. także Benedykt XVI, Jeśli chcesz krzewić pokój, strzeż dzieła stworzenia. Orędzie na Światowy Dzień Pokoju (1 I 2010), w: K. Szczygieł, W trosce o życie. Wybrane dokumenty Stolicy Apostolskiej, t. 2, Tarnów 2012, s. $437-444$.

${ }^{21}$ LS 105

${ }^{22}$ Por. LS 123.

${ }^{23}$ LS 109. 
ingerencji w naturalne środowisko. Rozwiązanie problemów ekologicznych ma zgodnie z tą wiarą przynieść sam rozwój bądź mechanizmy rynkowe, człowiek natomiast czuje się niemalże bezbronny wobec okoliczności uwarunkowanych przez technikę i prawa rynku. W ten sposób powstaje duch „zglobalizowanej techniki, w której nieustanna nowość produktów łączy się z ciążącą nudą"24.

W kryzysie ekologicznym ujawnia się znacznie głębszy kryzys etyczny, kulturowy i duchowy nowoczesności. Jego charakterystycznym elementem jest kultura relatywizmu, która nie dostrzega i nie jest gotowa respektować żadnych prawd obiektywnych. Na ten aspekt współczesnego kryzysu, już nie tylko ekologicznego, ale kulturowo-etycznego, wskazywał ze szczególnym naciskiem Benedykt XVI, mówiąc nawet o „dyktaturze relatywizmu"25. W obliczu braku obiektywnych zasad moralnych, gdy jedynym punktem odniesienia jest pragnienie zaspokojenia indywidualnych aspiracji i dążeń, ,jakie ograniczenia może mieć handel ludźmi, organizacje przestępcze, przemyt narkotyków, handel «krwawymi diamentami» czy skórami zwierząt zagrożonych wyginięciem?"26. W ramach globalnej dominacji technokratycznego paradygmatu nie jest możliwa nie tylko skuteczna i długofalowa ochrona środowiska, ale też budowanie prawdziwie ludzkiego społeczeństwa. Nawet jak najbardziej słuszne i obowiązujące zasady, jak np. zasada wolności gospodarczej, mogą zostać wykrzywione i zdeprawowane. Dlatego też ochrona środowiska nie może być jedynie ostatnim elementem w planach rozwojowych, obliczonym na minimalizację strat bądź wręcz jedynie zabiegiem wizerunkowym. Powinna ona być jednym z kluczowych elementów każdego planu zrównoważonego rozwoju.

\section{EKOLOGIA LUDZKA}

Drugim ważnym, wręcz kluczowym pojęciem encykliki Laudato si' jest pojęcie ekologii ludzkiej. Pojęcie human ecology pojawiło się w kontekście nauk przyrodniczych i humanistycznych, gdzie oznaczało interdyscyplinarne podejście do wzajemnych wpływów i zależności między człowiekiem a środowiskiem ${ }^{27}$. W nauczaniu Magisterium Kościoła pojęcie ekologii ludzkiej nabrało jednak szczególnego znaczenia. W jednej ze swoich encyklik społecznych Jan Paweł II przywołał je, stwierdzając, że obok ochrony habitatu różnych żywych stworzeń, niezbędna jest „ochrona warunków moralnych prawdziwej «ekologii ludzkiej»”28.

${ }^{24}$ LS 113.

${ }^{25}$ Por. Świattość świata. Papież, Kościót i znaki czasu. Benedykt VI w rozmowie z Peterem Seewaldem, Kraków 2011, s. 61-70. Zob. także J. Warzeszak, «Dyktatura» relatywizmu w ujęciu Benedykta XVI, „Warszawskie Studia Teologiczne” 24 (2011), s. 291-322.

${ }^{26}$ LS 123.

27 Por. np. B. Glaeser, Humanökologie: Der sozialwissenschaftliche Ansatz, „Naturwissenschaften" 83 (1996), vol. 4, s. 145-152.

${ }^{28} \mathrm{CA} 38$. 
Według Jana Pawła II niedostateczne uwzględnienie takiego spojrzenia prowadzi przede wszystkim do zagubienia szacunku dla życia człowieka ${ }^{29}$. Pojęcie ekologii ludzkiej podjął również Benedykt XVI, pisząc, że powinno się nie tylko słuchać języka otaczającej go przyrody, by móc stosownie odpowiadać na pojawiające się wyzwania, ale powinno się respektować także ekologię człowieka.

Również człowiek ma naturę, którą winien szanować i którą nie może manipulować dla własnej przyjemności. Człowiek nie jest tylko wolnością, którą się tworzy dla niej samej. Człowiek nie stwarza sam siebie. Jest on duchem i wolą, ale jest też natura, a jego wola jest słuszna wtedy, kiedy słucha on także natury, kiedy ją szanuje i przyjmuje siebie takiego jakim jest, że nie uczynił sam siebie. Właśnie w ten sposób i tylko w ten sposób urzeczywistnia się prawdziwa ludzka wolnośćc ${ }^{30}$.

Przywołując te motywy nauczania swoich poprzedników, papież Franciszek rozwija je, czyniąc z nich niemalże kluczowe pojęcie chrześcijańskiej myśli ekologicznej, które odróżnia ją od innych nurtów ekologicznych ${ }^{31}$. Przy całej trosce o przyrodę nie dostrzega się w nich bowiem kwestii centralnej: pytania o koncepcję człowieka. Tymczasem, jak podkreśla Franciszek, „nie da się utworzyć nowej relacji z naturą bez odnowionego człowieka. Nie ma ekologii bez właściwej antropologii" ${ }^{32}$.

W Laudato si' pojęcie ekologii ludzkiej obejmuje przede wszystkim szacunek dla moralnych uwarunkowań życia ludzkiego. Jak powiada Franciszek, chodzi o „niezbędną relację życia człowieka z prawem moralnym, wpisanym w jego naturę, relację konieczną, by można było stworzyć bardziej godne środowisko"33. Charakteryzuje się ona szacunkiem dla każdej istoty ludzkiej, niezależnie od jej stanu zdrowia, znaczenia społecznego czy też fazy rozwojowej. Z właściwą sobie jednoznacznością Franciszek stwierdza: „Jeśli nie uznaje się [...] znaczenia człowieka ubogiego, ludzkiego embrionu, osoby niepełnosprawnej - by podać tylko kilka przykładów - trudno będzie usłyszeć wołanie samej przyrody [...]. Nie da się pogodzić obrony przyrody z usprawiedliwianiem aborcji” ${ }^{34}$. W ten sposób ochrona życia nienarodzonych, kojarzona zazwyczaj z katolicką wrażliwością i wyłącznie religijną argumentacją etyczną, okazuje się wymogiem całościowo rozumianej ekologii.

${ }^{29}$ PG 70. Zob. też S. Jaromi, Koncepcja ekologii ludzkiej według Jana Pawła II, „Fides et Ratio" 10 (2012), z. 2, s. 5-12.

${ }^{30}$ Benedykt XVI, Przemówienie w Bundestagu, w: http://www.opoka.org.pl/aktualnosci/ news.php?id=39463\&s=opoka [dostęp: 7.06.2016]. Także CiV 48.

${ }^{31}$ Krótkie kompendium chrześcijańskiego znaczenia pojęcia human ecology można znaleźć w: M. Wyrostkiewicz, Human Ecology. An Outline of the Concept and the Relationship between Man and Nature, Lublin 2013.

${ }^{32}$ LS 118.

${ }^{33}$ LS 155.

${ }^{34} \operatorname{LS} 117,120$ 
Wśród różnych aspektów człowieczeństwa, które powinny podlegać ochronie w ramach całościowo rozumianej ekologii ludzkiej, szczególne miejsce zajmuje cielesność. Jest ona darem Boga, który powinien zostać zaakceptowany i uszanowany. Tam, gdzie pojawia się tendencja do dominacji nad własnym ciałem, szybko pojawia się mentalność naznaczona chęcią panowania nad stworzeniem $^{35}$. Oznacza to również docenienie własnego ciała w jego kobiecości lub męskości. Papież piętnuje tendencje, które usiłują zatrzeć różnicę płci, bo, jak stwierdza, nie potrafią z nią się konfrontować ${ }^{36}$.

Innym istotnym wymiarem ekologii ludzkiej jest niewatpliwie wspomniana już wyżej troska o dobro wspólne, a więc o całość warunków niezbędnych do tego, by każdy człowiek miał szansę rozwoju. Również to pojęcie ma za sobą długą historię i należy do kluczowych pojęć katolickiej nauki społecznej ${ }^{37}$. Franciszek podkreśla w tym kontekście aspekt ekologii ludzkiej, który był istotny także dla jego poprzedników ${ }^{38}$, a mianowicie troskę o rodzinę, która jest pierwszym, naturalnym i najlepszym „habitatem” człowieka. Umożliwia ona rozwój osobowy w atmosferze wzajemnej miłości, przygotowujący do życia w społeczeństwie oraz uczący między innymi również myślenia ekologicznego. Jako miejsce integralnej formacji dorastającego człowieka zapewnia ona harmonijne powiązanie różnych aspektów osobistego dojrzewania ${ }^{39}$.

Obok rodziny naturalny habitat człowieka stanowi także kultura. Nie ulega wątpliwości, że niszczenie bogactwa kulturowego zubaża ludzkość. Jak powiada papież, „zanik pewnej kultury może być równie albo jeszcze bardziej poważny jak wyginięcie gatunku zwierząt lub roślin. Narzucenie pewnego hegemonicznego stylu życia związanego z określonym sposobem produkcji może być równie szkodliwe jak zniszczenie ekosystemu" ${ }^{40}$.

Ekologia ludzka zwraca uwage nie tylko na relacje człowieka ze środowiskiem, ale również na znaczenie relacji społeczno-ekonomicznych, a więc na coś, co można by określić jako „środowisko społeczne”. Trosce o przetrwanie gatunków, przybierającej czasami rozmiary prawdziwej obsesji, towarzyszy nierzadko brak wyczulenia na uszanowanie równej godności wszystkich istot ludzkich ${ }^{41}$. Kluczowe są tu stworzone przez człowieka struktury społeczne, ekonomiczne i polityczne, które decydują o poziomie zamożności, możliwości znalezienia pra-

\footnotetext{
${ }^{35}$ LS 155.

${ }^{36}$ Tamże. Wydaje się, że papież krytykuje tutaj logikę wyrastającą z genderowego podejścia do cielesności.

37 Zob. KNSK, 164-170. Zob. też U. Nothelle-Wildfeuer, Die Sozialprinzipien der Katholischen Soziallehre, w: Handbuch der Katholischen Soziallehre, dz. cyt., s. 143-163.

${ }^{38}$ CA 39.

${ }^{39}$ LS 123, 213.

${ }^{40}$ LS 145

${ }^{41}$ Por. LS 90.
} 
cy oraz otrzymywaniu za nią godnej zapłaty. Wraz z wysiłkami zmierzającymi do uzdrowienia relacji człowieka ze środowiskiem naturalnym musi zatem postępować uzdrowienie podstawowych relacji międzyludzkich, gdyż kryzys ekologiczny jest ściśle powiązany z kryzysem społecznym i kulturowym, którego źródłem jest kryzys antropologiczny ${ }^{42}$. Papież Franciszek ostrzega przed małodusznym podejściem, polegającym wyłącznie na szukaniu kompromisów między ochroną środowiska a przychodami finansowymi oraz postępem. Takie drogi pośrednie okażą się szybko jedynie odsuwaniem w czasie nieuchronnej katastro$\mathrm{fy}^{43}$. Jednocześnie jednak do celu nie doprowadzą rozwiązania radykalne, które zazwyczaj uderzają w najbiedniejszych. Redukcja działań przemysłowych, które najsilniej degradują środowisko, powinna dokonywać się stopniowo, z nastawieniem na rozwiązania przejściowe oraz respektem wobec tych krajów, którzy będą ponosiły wyższe koszty działań chroniących środowisko, związanych np. z transformacją energetyczną. Natomiast „kraje, które skorzystały z wysokiego stopnia uprzemysłowienia kosztem ogromnej emisji gazów cieplarnianych, mają większą odpowiedzialność, by przyczynić się do rozwiązania problemów, które same spowodowały"44.

\section{EKOLOGIA TO TAKŻE OKREŚLONA DUCHOWOŚĆ}

By ochrona środowiska okazała się skuteczna, kluczową kwestią są jednak nie tyle globalne działania i programy - jakkolwiek byłyby niezbędne - ile zmiana mentalności jednostek. To właśnie obsesyjny konsumpcjonizm jednostek stwarza struktury, które ostatecznie są odpowiedzialne za degradację środowiska. Dlatego Franciszek proponuje z jednej strony program wychowania do przymierza między ludzkością a środowiskiem. Przymierze to ma przełożenie na konkretne i codzienne zachowania człowieka, jak np. oszczędność bądź też nawyk oddawania odpadów do utylizacji. ,Jeśli dana osoba, mimo że jej zasoby materialne pozwalają na większe wydatki, zazwyczaj ubiera się cieplej, zamiast włączać ogrzewanie, to znaczy, że nabyła przekonań i odczuć sprzyjających ochronie środowiska" ${ }^{45}$. Z drugiej strony papież podkreśla znaczenie postawy, którą określa jako „duchowość ekologiczna”. Nie waha się przy tym akcentować konieczności nawrócenia ekologicznego. Polega ono na umacnianiu głębokich motywacji proekologicznych, aby umacniać pasję na rzecz troski o świat. Duchowość ekologiczna, która wypływa z inspiracji chrześcijańskich, prowadzi do świadomości cudownego braterstwa z całym stworzeniem oraz do rewizji własnego stylu ży-

\footnotetext{
42 Por. LS 119.

${ }^{43}$ LS 194.

${ }^{44}$ LS 170.

${ }^{45}$ LS 211.
} 
cia w kierunku rozwoju postawy wstrzemięźliwości i zdolności do radowania się z posiadania niewielu rzeczy. „To powrót do prostoty, która pozwala nam się zatrzymać i docenić to, co małe i dziękować za możliwości, jakie daje życie, nie przywiązując się do nich, ani nie smucąc z powodu tego, czego nie posiadamy" ${ }^{46}$.

W działaniach na rzecz ochrony środowiska istotną rolę mogą odegrać światowe religie. To właśnie one sprawiaja, że wielkie możliwości nauki i techniki są postrzegane w szerszym kontekście sensu ludzkiej egzystencji, bez którego postęp przestaje być w pełni ludzki i może stać się destruktywny. Franciszek przestrzega przy tym przed eliminowaniem języka religijnego z debaty publicznej i zastępowaniem go refleksją wyłącznie laickiej etyki jako rzekomo neutralnej i lepiej przystosowanej do społeczeństwa pluralistycznego. Jak twierdzi papież, „naiwne jest sądzenie, że zasady etyczne można przedstawić w sposób czysto abstrakcyjny, oderwany od jakiegokolwiek kontekstu, a fakt, że pojawiają się one w języku religijnym, nie odbiera im żadnej wartości w debacie publicznej”"47.

\section{ZAKOŃCZENIE}

Laudato si' nie jest po prostu ,zieloną encykliką”. Chociaż właśnie w środowiskach współczesnych ekologów i mediach uznających siebie za postępowe ten dokument Magisterium Kościoła spotkał się z wręcz entuzjastycznym przyjęciem $^{48}$, jego bliższa lektura ukazuje go jako głęboko zakotwiczony w chrześcijańskiej antropologii, która podkreśla integralną wizję człowieka jako cielesno-duchowej jedności. Z chrześcijańskiego punktu widzenia ekologia to nie tylko postulaty ochrony środowiska, ale także ochrona samego człowieka we wszystkich wymiarach jego egzystencji. Przyroda i człowiek wraz z całą swoją kulturą materialną i duchową to tak integralnie splecione ze sobą rzeczywistości, że nie można skutecznie i na dłuższą metę chronić jednego z nich bez ochrony pozostałych. Ekologia wymaga czegoś więcej niż tylko ochrony habitatów zagrożonych gatunków oraz zasobów naturalnych.

Chociaż treści zawarte w Laudato si' nie są nowe i pojawiały się już wcześniej w nauczaniu poprzedników obecnego papieża, to jednak pozostaje niewątpliwą jego zasługą zebranie ich w jednym dokumencie i zaprezentowanie światu spójnej koncepcji chrześcijańskiej ekologii jako wkładu w toczącą się ekologiczną debatę. Największą wartością tej encykliki jest to, że główne postulaty etyczne dotyczące stosunku do życia, jakie wynikaja po prostu z osobistego przyjęcia

46 LS 222.

${ }^{47}$ LS 199.

48 Przykładem może być niezwykle pozytywny komentarz przewodniczącej niemieckiej Partii Zielonych Bündnis 90/Die Grünen, Katrin Göring-Eckardt. Zob. K. Göring-Eckardt, Mehr als ein Weckruf, sondern Kairos, w: Papst Franciscus, Die Enzyklika „Laudato Si”. Über die Sorge für das gemeinsame Haus, Freiburg i. Breisgau 2015, s. 19-34. 
Ewangelii przez osoby wierzące, zostały w tym dokumencie przedstawione jako elementy konsekwentnej i szeroko rozumianej ekologii, zrozumiałej i możliwej do zaakceptowania także przez osoby niewierzące. Jest to mimo to ekologia chrześcijańska, a więc oparta na wierze w Boga, który jest nieustannie obecny w centrum tego świata jako kochający Pan i Miłośnik życia. „On nas nie opuszcza, nie zostawia nas samymi. Bo definitywnie zjednoczył się z naszą ziemia, a jego miłość zawsze prowadzi nas do znalezienia nowych dróg. Jemu niech będzie chwała!"49.

\section{SUMMARY}

The aim of the encyclical of Pope Francis „Laudato Si” is neither settling of the controversies around the reasons of the ecological crisis, nor making concrete proposals for its solution. The Pope reveals rather the deep roots of the crisis. They are inherent in a greedy and mindless attitude to the environment. That attitude leads to a kind of ,wasteful and consumerist superdevelopment”. It means that only a few profit from the resources of the earth, which have originally been destined for all. One of the keywords for understanding the encyclical is doubtlessly a term ,human ecology". According to that term not only the habitats of plants and animals should be protected but also human life and the requirements of the human nature, independently from their development stage, health and social status. The ecology is according to Pope Francis not a marginal subject of Christian reflection but it refers to the essence of Christian life founded on the Gospel itself. That is why the ecological spirituality is also very important. It enables to shape the adequate attitude to every human being and to the natural world.

\section{Keywords}

Pope Francis, ecology, sustainable development, overdevelopment, human ecology, the poor, ecological spirituality

\section{WYKAZ SKRÓTÓW}

CA Jan Paweł II, Encyklika Centessimus annus w setną rocznicę encykliki Rerum novarum.

CiV Benedykt XVI, Encyklika Caritas in veritate o integralnym rozwoju ludzkim w miłości i prawdzie.

EG Franciszek, Adhortacja apostolska Evangelii gaudium o głoszeniu Ewangelii w dzisiejszym świecie.

EV Jan Paweł II, Encyklika Evangelium vitae o wartości i nienaruszalności życia ludzkiego.

KDK Sobór Watykański II, Konstytucja duszpasterska o Kościele w świecie współczesnym Gaudium et spes.

${ }^{49}$ LS 245. 
KKK Katechizm Kościoła katolickiego

KNSK Papieska Rada Iustitia et Pax, Kompendium nauki społecznej Kościoła.

LS Franciszek, Encyklika Laudato si’. W trosce o wspólny dom.

PG Jan Paweł II, Adhortacja apostolska Pastores gregis o biskupie słudze Ewangelii Jezusa Chrystusa dla nadziei świata.

\section{BIBLIOGRAFIA}

Benedykt XVI, Encyklika Caritas in veritate o integralnym rozwoju ludzkim w miłości i prawdzie. Tekst polski w: W trosce o życie. Wybrane dokumenty Stolicy Apostolskiej, t. 2, red. J. Brusiło, Biblos: Tarnów 2012, s. 98-150.

Benedykt XVI, Jeśli chcesz krzewić pokój, strzeż dzieła stworzenia. Orędzie na Światowy Dzień Pokoju (1 I 2010), w: K. Szczygieł, W trosce o życie. Wybrane dokumenty Stolicy Apostolskiej, t. 2, Biblos: Tarnów 2012, s. 437-444.

Benedykt XVI, Przemówienie w Bundestagu, http://www.opoka.org.pl/aktualnosci/news. php?id=39463\&s=opoka [dostęp: 7.06.2016].

Franciszek, Adhortacja apostolska Evangelii gaudium o głoszeniu Ewangelii w dzisiejszym świecie. Tekst polski: Wydawnictwo M: Kraków 2013.

Franciszek, Encyklika Laudato si’. W trosce o wspólny dom. Tekst polski: Wydawnictwo M: Kraków 2015.

Franciszek, Medytacja podczas Mszy św. 9 lutego 2015, http://w2.vatican.va/content/fran cesco/it/cotidie/2015/documents/papa-francesco-cotidie_20150209_al-lavoro-con-dio. html [dostęp: 20.05.2016].

Glaeser B., Humanökologie: Der sozialwissenschaftliche Ansatz, „Naturwissenschaften” 83(1996), vol. 4, s. 145-152.

Göring-Eckardt K., Mehr als ein Weckruf, sondern Kairos, w: Papst Franciscus, Die Enzyklika Laudato si’ Die Umweltenzyklika des Papstes, Herder: Freiburg i. Breisgau 2015, s. 19-34.

Gruber F., Im Haus des Lebens. Eine Theologie der Schöpfung, Pustet: Regensburg 2001, S. $155-174$.

Jan Paweł II, Encyklika Centessimus annus w setną rocznicę encykliki Rerum novarum (1991), http://www.opoka.org.pl/biblioteka/W/WP/jan_pawel_ii/encykliki/centesimus _1.html [dostęp: 18.08.2016].

Jan Paweł II, Pokój z Bogiem Stwórca, pokój z catym stworzeniem, w: http://papiez.wia ra.pl/doc/378717.Pokoj-z-Bogiem-Stworca-pokoj-z-calym-stworzeniem-1990 [dostęp: 25.05.2016].

Jan Paweł II, Encyklika Evangelium vitae o wartości i nienaruszalności życia ludzkiego. Tekst polski: W trosce o życie. Wybrane dokumenty Stolicy Apostolskiej, t. 1, red. K. Szczygieł, Biblos: Tarnów 1998, s. 41-134. 
Jan Paweł II, Adhortacja apostolska Pastores gregis o biskupie słudze Ewangelii Jezusa Chrystusa dla nadziei świata. Tekst polski: Wydawnictwo M: Kraków 2003.

Jaromi S., Koncepcja ekologii ludzkiej wedlug Jana Pawła II, „Fides et Ratio” 10(2012), z. 2, s. 5-12.

Katechizm Kościoła katolickiego, Pallottinum: Poznań 1994.

Kehl M., Schöpfung. Warum es uns gibt, Herder: Freiburg i. Breisgau 2005, s. 16-20.

Korff W., Lexikon der Bioethik, t. 1, Gütersloher Verlagshaus: Gütersloh 2000, s. 15.

Nothelle-Wildfeuer U., Die Sozialprinzipien der Katholischen Soziallehre, w: Handbuch der Katholischen Soziallehre, red. A. Rauscher, Berlin 2008, s. 143-163.

Papieska Rada Iustitia et Pax, Kompendium nauki społecznej Kościoła. Tekst polski, Wydawnictwo Jedność: Kielce 2005.

Roos L., Die Sozialenzykliken der Päpste, w: Handbuch der Katholischen Soziallehre, red. A. Rauscher, Duncker\&Humblot: Berlin 2008, s. 125-142.

Römelt J., Christliche Ethik in modern er Gesellschaft. 2 Lebensbereiche, Herder: Freiburg-Basel-Wien 2009, s. 322-324.

Sobór Watykański II, Konstytucja duszpasterska o Kościele w świecie współczesnym Gaudium et spes. Tekst polski, w: Sobór Watykański II, Konstytucje - Dekrety - Deklaracje, Pallotinum: Poznań, s. 811-987.

Mariański J., Odpowiedzialność człowieka za środowisko naturalne i ekologię ludzka w świetle społecznego nauczania Kościoła, w: Fructus Spiritus est caritas. Księga Jubileuszowa ofiarowana Księdzu Profesorowi Franciszkowi Draczkowskiemu, red. M. Wysocki, Wydawnictwo KUL: Lublin 2011, s. 814.

Schockenhoff E., Anthropozentrische und ökozentrische Ethik, w: Handbuch der Katholischen Soziallehre, red. A. Rauscher, Duncker\&Humblot: Berlin 2008, s. 410.

Świattość świata. Papież, Kościót i znaki czasu. Benedykt VI w rozmowie z Peterem Seewaldem, Znak: Kraków 2011, s. 61-70.

Warzeszak J., «Dyktatura» relatywizmu w ujęciu Benedykta XVI, „Warszawskie Studia Teologiczne" 24(2011), s. 291-322.

Wyrostkiewicz M., Human Ecology. An Outline of the Concept and the Relationship between Man and Nature, Wydawnictwo KUL: Lublin 2013.

Vogt M., Das Konzept der Nachhaltigkeit, w: Handbuch der Katholischen Soziallehre, red. A. Rauscher, Duncker\&Humblot: Berlin 2008, s. 411-419.

Marian Machinek, ur. 1960, kapłan Zgromadzenia Misjonarzy Świętej Rodziny (MSF), profesor teologii, profesor Uniwersytetu Warmńsko-Mazurskiego w Olsztynie, kierownik Katedry Teologii Moralnej i Etyki na Wydziale Teologii Uniwersytetu Warmińsko-Mazurskiego w Olsztynie. Przewodniczący Stowa- 
rzyszenia Teologów Moralistów, członek Komitetu Nauk Teologicznych Polskiej Akademii Nauk, Polskiego Towarzystwa Bioetycznego, Association of Bioethicists in Central Europe (BCE), Europäische Gesellschaft für Katholische Theologie (ET), Internationale Vereinigung für Moraltheologie und Sozialethik, redaktor naczelny rocznika Wydziału Teologii UWM „Forum Teologiczne” (2003-2015). Od 2015 redaktor naczelny Studiów Nauk Teologicznych PAN. 